\title{
BEVACIZUMAB AS MAINTENANCE TREATMENT IN PATIENTS WITH OVARIAN CANCER
}

DOI: $10.31618 /$ ESU.2413-9335.2019.2.69.481

Akhmedov Odiljon Mukhammadjanovich

$M D, P h D$.

The main doctor of Republican specialized

Scientific and Practical Medical Center of Oncology and Radiology of the Ministry of Health of the Republic of Uzbekistan, Tashkent

\begin{abstract}
The article discusses the use of the drug bevacizumab in patients with ovarian cancer.

\section{АННОТАЦИЯ}

В статье рассматривается применение препарата бевацизумаб у больных раком яичников.

Key words: ovarian cancer, chemotherapy, bevacizumab.

Ключевые слова: рак яичников, химиотерапия, бевацизумаб.
\end{abstract}

In their recent article published in Journal of Clinical Oncology, Tewari et al highlighted that in the GOG0218 trial, neither first-line bevacizumab concurrent with chemotherapy nor bevacizumab concurrent with chemotherapy plus maintenance significantly improved overall survival (OS) compared with chemotherapy alone, even though bevacizumab administered throughout treatment has prolonged median progression-free survival (PFS) by approximately 4 months. Moreover, the authors demonstrated that germ line or somatic mutations in BRCA1/2 genes were prognostic, but not predictive, of bevacizumab efficacy.

However, the median OS for patients with BRCA mutations was the same in the control and maintenance bevacizumab arms (62.5 and 62.6 months, respectively), whereas in BRCA wild-type patients, bevacizumab led to a 3-month improvement in OS, although this was not statistically significant.[7] Again, maintenance bevacizumab led to a median PFS improvement only in patients without mutations (15.7 v 10.6 months; hazard ratio [HR], $0.71 ; 95 \%$ CI, 0.60 to 0.85 ; P 5 .0001), not in those with mutations (HR, $0.95 ; 95 \%$ CI, 0.71 to 1.26 ). [1-3] Similarly, in the AGOOVAR 16 phase III randomized trial of maintenance pazopanib versus placebo after first-line chemotherapy, a clinically meaningful difference in efficacy with pazopanib for PFS according to BRCA status was seen, with a median PFS significantly longer for the pazopanib arm versus placebo in BRCA wildtype patients (17.7 v 14.1 months; HR, 0.77; 95\% CI, 0.62 to 0.97 ; P 5 .024); median PFS was not significantly different in those with BRCA mutations (30.2 v 30.3 months; HR, 1.36; $95 \%$ CI, 0.66 to 2.82; P $5.41)$. [4]

In a recent phase II randomized trial in patients with platinum-sensitive relapsed ovarian cancer, [5] niraparib plus bevacizumab significantly prolonged the median PFS when compared with niraparib alone (11.9 v 5.5 months; HR, 0.35 ; $95 \%$ CI, 0.21 to 0.57 ; P .0001). This improvement was reported in BRCA wild-type patients $(11.3$ v 4.2 months; HR, $0.32 ; 95 \% \mathrm{CI}, 0.17$ to 0.58; P 5 .0001), but not in those with BRCA mutations (14.4 v 9.0 months; HR, 0.49; 95\% CI, 0.21 to 1.15 ; P 5 .095), suggesting that BRCA-mutated tumors may not need the combination with bevacizumab.
A biologic explanation behind these findings could be related to the tumor microenvironment. Indeed, BRCA1 plays an important role in hypoxiainduced expression of VEGF, and less HIF-1 accumulates in hypoxic conditions in BRCA-deficient cells, but not in normoxic conditions or BRCAproficient cells.6 Moreover, BRCA-disrupted tumors present more frequently an immunereactive subtype, with a higher presence of tumor-infiltrating lymphocytes (TILs), whereas a stromal or mesenchymal subtype expresses fewer immune cell genes and more angiogenesis-related genes [7]. Therefore, it could be hypothesized that bevacizumab is less active in BRCA-mutated ovarian cancer.

In this context, inflammation may play a fundamental role. Neutrophil-to-lymphocyte ratio (NLR) is one of the most widely used systemic inflammatory marker and is able to assess the balance between neutrophil dependent protumor inflammation and lymphocyte associated antitumor immune response, with a high NLR associated with poor survival in different treatments, including immune checkpoint inhibitors [8]. In a real-world retrospective study, we showed that a high NLR (\$3) was associated with an improvement in median PFS and OS in patients with ovarian cancer treated with bevacizumab compared with controls, [9 ] and in a subanalysis, we recently observed an association between high NLR and BRCA wild-type status (82\%). Moreover, a correlation between high TIL number and low NLR has been already demonstrated, [10] suggesting that in low immunereactive tumors, bevacizumab may increase the number of CD81 and CD41 $\mathrm{T}$ cells and reduce suppressive cytokines, tumor-infiltrating T-regulatory cells, and myeloid-derived suppressor cells, which ultimately could improve adaptive immunity. Inflammatory indexes such as NLR could serve as helpful predictive tools, when validated in prospective trials.

In their conclusions, the authors argued that PFS may have more clinically meaningful value, because the lack of improvement in OS may have been obscured by crossover and/or postprogression therapies. Such considerations led the authors to conclude that patients without contraindications may initiate bevacizumab while waiting for BRCA testing results, stating that 
patients "with BRCA1/2 mutated carcinoma can be transitioned to maintenance olaparib, whereas those without mutations may remain on maintenance bevacizumab."[7 p2326]

We have some concerns with these conclusions. The blinding of the treatment assignments after disease progression was contested; also, the primary end point of the GOG-0218 trial was modified from OS to PFS, and any other comparison became a secondary objective [2]. Moreover, the only arm that reached the primary end point in the study, resulting in a PFS improvement, was the arm receiving concurrent bevacizumab and chemotherapy plus maintenance, whereas results for the arm in which bevacizumab was stopped after chemotherapy did not differ from those for the control group [2]. Therefore, before incorporating bevacizumab into the treatment of patients with ovarian cancer, we suggest waiting for the results of BRCA testing.

\section{REFERENCES}

Камышов С.В., Пулатов Д.А., Юлдашева Н.Ш. Изучение роли молекулярно-биологических маркеров опухоли в выборе метода иммунотерапии в сопроводительном лечении рака яичников и рака шейки матки Евразийский онкологический журнал. 2015. № 2 (5). С. 53-60.

Камышов С.В., Пулатов Д.А., Юлдашева Н.Ш. Изучение роли экстракорпоральной иммунофармакотерапии в снижении токсических эффектов химиолучевой терапии у пациентов с раком шейки матки Евразийский онкологический журнал. 2015. № 4 (7). С. 28-34.

Камышов С.В., Пулатов Д.А., Ахмедов О.М., Саидова К.А., Алиева Д.А., Гильдиева М.С., Нишанов Д.А. Влияние экстракорпоральной иммунофармакотерапии на внутриклеточный метаболизм у пациентов с раком шейки матки Евразийский онкологический журнал. 2018. Т. 6. № 2. С. 551-562.

Камышов С.В. Механизмы иммунных нарушенийу пациентов с раком яичников, получающих химиотерапию, и их динамика на фоне иммунотерапии Евразийский онкологический журнал. 2018. Т. 6. № 2. С. 563-576.

Камышов С.В., Юлдашева Н.Ш., Салимова Л.Р. Изучение методов экстракорпоральной иммунофармакотерапии в качестве сопровождения химиотерапии у больных раком яичников Онкология и радиология Казахстана. 2010. № 3-4 (16-17). С. 96.

Юлдашева Н.Ш., Наврузова В.С., Ахмедов О.М., Умарова Н.А., Камышов С.В. Особенности лечебного патоморфоза опухоли при рентгенэндоваскулярной полихимиотерапии в комплексном лечении рака шейки матки Онкология и радиология Казахстана. 2010. № 3-4 (16-17). С. 96-97.

Tewari KS, Burger RA, Enserro D, et al: Final overall survival of a randomized trial of bevacizumab for primary treatment of ovarian cancer. J Clin Oncol 37:2317-2328, 2019

Burger RA, Brady MF, Bookman MA, et al: Incorporation of bevacizumab in the primary treatment of ovarian cancer. N Engl J Med 365:2473-2483, 2011

Norquist BM, Brady MF, Harrell MI, et al: Mutations in homologous recombination genes and outcomes in ovarian carcinoma patients in GOG 218: An NRG Oncology/Gynecologic Oncology Group study. Clin Cancer Res 24:777-783, 2018

Harter P, Johnson T, Berton-Rigaud D, et al: BRCA1/2 mutations associated with progression-free survival in ovarian cancer patients in the AGOOVAR 16 study. Gynecol Onocol 140:443-449, 2016

Alimkhodjaeva L.T. Features of Cellular, humoral and activation markers of immune syste $m$ and biophysical parametersof superficial membanes of lymfhocytes of periphery blood at patients with a breast cancer // HAIWAI YINGYU- China, 2010 № 4-p.216219

Alimkhodjaeva L.T. The diagnostic value of the investigations of the proinflammatory and Antiinflammatory cytokines levels in the immune system of patients with breast cancer// HAIWAI YINGYUChina , 2010 № 4-p.216-219

UDC: $614.253: 616-006$

\title{
LEVERAGING CLINICAL TUMOR-PROFILING PROGRAMS TO ACHIEVE COMPREHENSIVE PRECISION CANCER MEDICINE
}

DOI: $10.31618 /$ ESU.2413-9335.2019.2.69.482

Israilbekova Kamilla Shavkatovna

MD, aspirant of Department Chemotherapy of Republican specialized Scientific and Practical Medical Center of Oncology and Radiology of them ministry of Health of the Republic of Uzbekistan, Tashkent

\section{УЛУЧШАЮЩИЕ КЛИНИЧЕСКИЕ ПРОГРАММЫ ПРОФИЛИРОВАНИЯ ОПУХОЛЕЙ ДЛЯ ДОСТИЖЕНИЯ МНОГОКРАТНОЙ ТОЧНОСТИ ОНКОЛОГИЧЕСКОЙ МЕДИЦИНЫ}

\author{
ABSTRACT \\ The article is devoted to the use of clinical programs for profiling tumors in terms of improving the accuracy \\ of cancer medicine.
}

\section{АННОТАЦИЯ}

Статья посвящена применению клинических программ профилирования опухолей с точки зрения повышения точности онкологической медицины.

Key words: clinical programs for tumor profiling, gremline, BRCA2, CHEK2, BRCA1. 